\title{
Uma história contada pelo avesso
}

\author{
Eneida Weigert Menna Barreto ${ }^{1}$
}

\begin{abstract}
Résumé: Cet article analyse 1' oeuvre de Luiz Antonio de Assis Brasil, et montre comment, à partir des données historiques, le narrateur / auteur démystifie la bravoure dans l'histoire du Rio Grande do Sul. L'auteur utilise la métafiction historiographique pour construire un nouveau passé. C' est comme il s' insere dans la post-modernité.
\end{abstract}

Mots-clés: Luiz Antonio de Assis Brasil, littérature, histoire, postmodernité

Resumo: Este trabalho analisa a obra de Luiz Antonio de Assis Brasil, e mostra como a partir dos dados históricos, o narrador/autor desmitifica a bravura na História do Rio Grande do Sul. O autor, ao utilizar a metaficção historiográfica, constrói um novo passado. Ao fragmentar a narrativa em múltiplas vozes, desautoriza a tentativa do leitor do século XXI de encontrar apenas uma verdade e, com isso, firma a impossibilidade de uma percepção única da verdade histórica. É como transpõe fronteiras discursivas e se insere na pós-modernidade.

Palavras-chave: Luiz Antonio de Assis Brasil, literatura, História, pósmodernidade

A história política do Rio Grande do Sul, em seus primórdios, esteve mesclada à história dos homens que o povoaram. As disputas de terras, principalmente nas fronteiras sulinas, exibiam o traço da beligerância, confundindo-se com projetos de dominação. Nesse sentido, as Missões ou a Colônia do Sacramento são exemplos da mobilidade dessas fronteiras. Servindo de mote para os interesses de cada uma das nações que as queriam explorar, esses redutos de civilização marcaram o permanente estado de alerta em que se encontravam, tendo em vista as ambições das nações peninsulares.

Tardiamente integrado ao restante do país (século XVI), o Rio Grande do Sul sofreu um processo de exploração tanto da população nativa - índios - como também de suas riquezas naturais. Sua história não fica distante das demais situações da América de então. Talvez, o que diferencie sua trajetória seja o longo período em que ficou à margem do processo de

1 Este artigo tem sua origem em tese de doutoramento defendida na UFRGS, com orientação da Profa. Dra. Jane Tutikian 
colonização devido às suas próprias características que não correspondiam às exigências da Metrópole em relação à colônia: exploração mineral e/ou produção agrícola. A nenhum desses quesitos integrava-se o Rio Grande do Sul e, por isso, não despertava a cobiça.

Foi sob a bandeira espanhola que o Rio Grande do Sul iniciou seu processo civilizatório. Os jesuítas, segundo Pesavento ${ }^{2}$, “ocuparam uma área que se estendeu pela zona de Ijuí, (...) Rio Pardo, fundando reduções, onde dedicaram-se à agricultura e formaram estâncias de criação de gado trazido da província Argentina de Corrientes". Assim, após confrontos com paulistas que vinham em busca da mão-de-obra indígena, abandonaram esses redutos colonizadores, retirando-se para o Uruguai. O gado, tendo ficado à deriva, tornou-se bravio, vindo a formar o "fundamento econômico" dos primeiros tempos do Rio Grande do Sul: "preia do gado xucro"3, a origem do gado chimarrão 4

O Rio Grande do Sul, desde O Tempo e o Vento, de Erico Verissimo, tem contribuído com uma plêiade de escritores voltados à narrativa da formação do espaço rio-grandense, em que a ocupação do território é fator determinante para caracterizar o tipo humano que ali se instala. Dentre esses escritores, está Josué Guimarães, e, mais recentemente, Luiz Antonio de Assis Brasil, Tabajara Ruas e José Clemente Pozenato, entre outros.

E é exatamente sobre a ocupação desses espaços que falamos: a forma como a arte acrescentou à vida aquilo que lhe faltou ou que talvez, manipulado, ficou às ocultas nos desvãos do tempo. Retomado de outro viés, ilumina o registro e é iluminado por ele.

Para Luiz Antonio de Assis Brasil, representar literariamente uma época histórica já faz parte de seu percurso como escritor. Sendo assim, iniciando a década de 1990, publica entre os anos de 1992 e 1994 a obra intitulada Um Castelo no Pampa, que não destoa de suas narrativas anteriores em relação ao registro histórico: focaliza o Rio Grande do Sul e a pluralidade de acontecimentos no período que vai de meados do século XIX até o golpe militar em 1964. Nesse ínterim, são lidas as questões políticas nacionais e da Província/ Estado, através da saga de uma família radicada na região da campanha. Ao reconstituir o espaço histórico, político e social do Estado, relacionando fatos e vultos que fizeram a História do Brasil daquela época, esse discurso, que aproxima o histórico e o literário, aponta também para a desconstrução da identidade mítica de nosso Estado. Reelaborando o passado nebuloso da história do Rio Grande do Sul, recupera a cosmogonia pampiana e dá contorno àquele tempo que se quer mítico. E a verdade oficial defronta-se com o preenchimento de suas lacunas.

As obras que compõem a narrativa: Perversas Famílias, Pedra da Memória e Os Senhores do Século, com arquitetura fragmentada nos três volumes, evidenciam uma ruptura espaço-temporal, reforçada com a troca de narradores em cada capítulo, os quais alternam o foco narrativo e não rompem com a construção coerente das personagens, apenas acrescentam detalhes.

Em Perversas Famílias, inicia-se a narrativa. Uma voz não identificada, que se apresenta em terceira pessoa, introduz, sem preâmbulos, o leitor na vida do Castelo.

2 PESAVENTO, Sandra Jathay. História do Rio Grande do Sul. 9 ed. Porto Alegre: Mercado Aberto, 2002.p.9

3 Idem.Ibidem.

4 Essa raça de gado, nomeada na obra Um Castelo no Pampa, de Luiz Antonio de Assis Brasil, foi motivo de desconforto para o protagonista da mesma, uma vez que não representava uma raça pura. Esse gado, por ocasião da colonização do Rio Grande, pertenceu aos jesuítas e, mais tarde, quando acabaram aqueles redutos jesuíticos, permaneceu como gado sem dono, espalhado pela vastidão do pampa gaúcho. Servia de alimento aos índios charruas, altamente belicosos e nômades, que habitavam o extremo sul do Rio Grande do Sul. Para aproveitar esse gado chimarrão, surgiram as charqueadas (CORRÊA, Romaguera, et al. Vocabulário RioGrandense. Rio de Janeiro, Porto Alegre: Globo, 1964. p. 122) 
Nesse volume, a História do Rio Grande do Sul aparece, principalmente, no final da Monarquia, com a problemática da abolição da escravatura em efervescência. Também tem relevância a Escola de Direito de São Paulo, em que alunos egressos do Rio Grande do Sul marcam seu espaço em favor da República. A atuação desses alunos já prenuncia seus lugares como protagonistas na cena política brasileira.

As questões no Estado evidenciam a forte presença positivista, sustentada na figura de Júlio de Castilhos e, posteriormente, na de Borges de Medeiros. Destaca-se, ainda, o horror da Revolução de 1893, que legou ao Estado um saldo de inúmeras mortes, muitas delas provocadas por degolas 5 .

O aspecto afetivo é assinalado pela morte do pai de Olímpio, que deixa o filho e a esposa, Dona Plácida, grávida de Arquelau. Também acompanhamos os últimos momentos da vida de Olímpio e seu encontro com Páris no Castelo. Além disso, o romance que resulta na ligação ilegítima de Dona Plácida com Felix Del Arroyo, professor de Arquelau, vem à tona com todo o drama vivido pela personagem.

Em Pedra da Memória, segundo volume, o autor mantém a estrutura narrativa fragmentada de contraponto. Olímpio já está formado em Direito e retorna da Europa noivo de uma Condessa austríaca. A política brasileira movimenta-se sob o regime republicano e o Positivismo solidifica-se como filosofia de governo. Não só no Rio Grande do Sul, como no Brasil, os governantes aderem à nova ideologia.

Acontece a Revolução de $1923^{6}$. Seu término ocorre com a assinatura do Tratado de Pedras Altas, representado pela união do governo e os senhores de terra. Estes lutaram para retirar Borges do governo. O encontro, na residência de Olímpio, chamada por ele de Castelo da Liberdade, teve também a presença de Getúlio Vargas, que despontava politicamente.

Apropriando-se da História, o literário reconstrói um notório fato histórico: o acordo firmado entre as facções implicadas na Revolução de 1923 teve lugar no Castelo de Pedras Altas, cujo proprietário era o estadista Joaquim Francisco de Assis Brasil.

Nascem os filhos de Olímpio e Charlotte: Aquiles, Proteu e Selene, corroborando com a perspectiva, vislumbrada ao longo da obra, da configuração de um enredo complexo. Por isso talvez possamos dizer que não há quebra ou ruptura para enredo simples, pois sempre se mostrou do mesmo modo.

Páris, o neto bastardo de Olímpio, e Astor, irmão renegado, são narradores e auxiliam a manutenção do ritmo fragmentado da narrativa. Estas duas personagens assumem boa parte do texto do segundo volume, retocando o passado com um olhar cheio de malícia, ironia e vulgaridade. Fatos inéditos são trazidos tanto por Astor, como por Páris. Este último é impelido a desvendar o segredo de seu nascimento.

5 As degolas ocorreram durante a Revolução Federalista, no Rio Grande do Sul, logo após a Proclamação da República, tendo como causa a instabilidade política gerada pelos federalistas, "maragatos", chefiados por Gaspar Silveira Martins, que lutavam para libertar a Província do Rio Grande das mãos de Júlio de Castilhos, então presidente do Estado. Entre fevereiro de 1893 a agosto de 1895, desencadeou-se uma guerra civil, vencida pelos pica-paus, seguidores de Júlio de Castilhos. As degolas foram consequência da impossibilidade das forças combatentes de manter os prisioneiros, bem como poupar munição empregando um meio rápido de execução(FLORES, Moacyr. História do Rio Grande do Sul. 7ed. Porto Alegre: EDIPLAT, 2003).

6 Movimento armado, ocorrido durante onze meses do ano de 1923 no Rio Grande do Sul, como consequência do resultado da eleição para presidente do Estado, em que concorria novamente Borges de Medeiros, tendo como opositor Joaquim Francisco de Assis Brasil. Devido à fraude nos resultados, em que venceu Borges de Medeiros, lutaram, de um lado, os partidários de Borges de Medeiros (borgistas ou chimangos) e, de outro, os aliados de Joaquim Francisco de Assis Brasil (assisistas ou maragatos) (FLORES, Moacyr. História do Rio Grande do Sul. 7ed. Porto Alegre: EDIPLAT, 2003). 
No terceiro volume, Os Senhores do Século, comemora-se a atuação de Olímpio, que soube reunir no Castelo, com ímpar habilidade política, os líderes da Revolução de 1923. Esse fato pôs fim a um litígio que já durava alguns anos e que fez do Rio Grande um vasto cemitério. A derrota dos revoltosos era previsível e Olímpio abranda suas conseqüências com o acordo.

Acontece a Revolução de $30^{7}$ e Getúlio Vargas torna-se presidente do Brasil, depois de ter governado o Estado rio-grandense. No romance, Olímpio é nomeado ministro pelo conterrâneo, que o considera também um dos senhores do século.

Como o fio narrativo da obra é um ir e vir, nesse volume são retomados aspectos que aparecem no primeiro, como a morte de Olímpio, por exemplo.

Do mesmo modo, as questões amorosas recebem atenção especial, salientadas pelos títulos dos capítulos: Romance I, Romance II, Romance III, Romance IV, Romance V e Romance VI, Epílogo. Relações ilícitas e, de acordo com a denúncia de hipocrisia que permeia a obra, as mais verdadeiras. $\mathrm{O}$ autor insiste em enfatizar os laços amorosos, fora do compromisso social da família, como os mais puros.

A designação de trilogia para a obra Um Castelo no Pampa, embora esteja difundida entre os leitores de L.A. de Assis Brasil, o autor, em nota no final de Pedra da Memória, afirma - "Não penso que Um castelo no pampa seja uma trilogia, mas uma série em três volumes, isto é: um único romance em seqüência". Essa informação encaminha também a metodologia para quem pretende estudar a obra: ela deve ser lida como um todo, pois ao fragmentar a análise, fragmenta-se o enredo e as personagens. Acompanhar, então, o desenrolar dos acontecimentos implica olhar a ação de cada personagem em seu conjunto, o que só será possível ao término dos três volumes. A ficcionalização do histórico, muitas vezes, anda pari passu com o que está registrado na História ou seu aproveitamento acontece de tal forma que reforça, no romance, a subversão do tempo que atinge a própria seqüência lógica da leitura; o leitor percebe que a montagem da obra é como um quebra-cabeça, por vezes, invertido, como demonstra a utilização de vários narradores que também não seguem uma ordem cronológica dos fatos. A análise da obra, portanto, deve abarcar uma visão de conjunto, sem estar delimitada por volume, pois esse procedimento resultaria no rompimento da cadeia discursiva.

O modo como L. A. Assis Brasil trabalha com os eventos sugere escolhas não aleatórias. Em suas criações, o ficcional, ao reorganizar o passado, consolida-se pelas figuras históricas que o povoa. Assim, não usa a História somente para cotejá-la, mas para realizar um trabalho metaficcional. Registrando a sociedade sul-rio-grandense, aponta para o modo como as relações humanas estão formadas, assinalando, também, as mudanças na sociedade, na política, com sua repercussão na vida doméstica.

Nesse sentido, o suporte das teorias de Linda Hutcheon (1991) corroborou para a análise da ficcionalização da História na obra, permitindo-nos, na maioria das vezes, verificar o distanciamento de seus registros: o autor recria os fatos, a partir de sua desconstrução histórica, resultando em uma visão desmistificadora da História.

Desse modo, a questão mítica pode ser rastreada em relação à visão fundacional do pampa, em aspectos históricos e geográficos. São marcas referendando um momento

7 Movimento armado envolvendo três estados: Minas Gerais, Paraíba e Rio Grande do Sul, culminando com o golpe de Estado que pôs fim à República Velha (FLORES, Moacyr. História do Rio Grande do Sul. 7ed. Porto Alegre: EDIPLAT, 2003.

$8 \mathrm{O}$ autor, em entrevista informal, afirmou que, por questões editoriais, havia optado por dividir a obra em três volumes. 
de inauguração do espaço geográfico das ações do romance e que remetem ao tempo da criação do lugar. Voltamos à época pioneira, quando o deslocamento nos campos, coxilhas e no lugar que se convencionalizou como campos "de Cima da Serra" (CORREA, 1964, p. 89), no Rio Grande do Sul se fazia de forma precária. A imagem de um tempo primitivo apresenta-se no texto, lado a lado com planos temporais diversificados, quebrando-se o encadeamento cronológico entre passado, presente e futuro.

$\mathrm{O}$ autor, ao denominar suas personagens inspirado em personagens da Antiguidade Clássica, faz o leitor suspeitar de uma narrativa épica para a história rio-grandense. Todavia, a proposta estética tem outra dimensão, pois os nomes míticos parecem estar na narrativa para ridicularizar e pôr a descoberto as farsas históricas relacionadas nos registros. Ao usar nomes e recorrências simbólicas o autor menospreza aquela visão da História, porque, no texto, o mito tem o objetivo de minimizar os atos do protagonista e da história que vivencia. A localização mítica encontra-se, no entanto, na construção textual do pampa, sinalizada também nas relações da formação do território rio-grandense. É como uma volta ao em illo tempore, uma vez que discorre, de forma metafórica ou não, sobre a criação do lugar primordial. O mito consolida-se, então, como resgate de um momento fundacional, tanto em relação ao pampa, quanto àquele que diz respeito ao alicerce de uma civilização. Aqui, poderíamos dizer, civilização européia, sem qualquer imposição ideológica, pois o Castelo de Olímpio, linguagem-objeto de nosso estudo, tanto no seu interior - com seus habitantes, adornos, cardápio - e seu exterior - com uma arquitetura de castelo medieval e todas as articulações de progresso em seu entorno - define-se europeu.

Assim, o mito retomado nos nomes próprios das personagens induz ao erro o leitor, que espera atitudes heróicas das personagens e, ao contrário, na construção do castelo, as referências aos mitos cosmogônicos eleva a estatura do castelo. $\mathrm{O}$ local em que o castelo foi erigido constitui-se, por esse viés, um espaço sagrado para as civilizações futuras. Dessa forma, o aparecimento da serpente e do ovo, símbolos fundacionais por excelência - elementos que irradiam o sagrado - remetem à origem do lugar.

Por outro lado, o Castelo, modificando o seu entorno, põe em evidência a postura ambígua de seu proprietário que se diz campônio, mas age como se europeu fosse. Recuperase, dessa maneira, o pampa em formação e o ato civilizatório, projetado na construção do castelo, serve de contraponto, destacando a relação barbárie e civilização.

O protagonista, ao implantar a civilização no pampa, confrontando-a com o espaço da barbárie, traz a imagem alegórica do colonizador/europeu penetrando e impondo-se nas terras do Novo Mundo. Desse modo, o trabalho de locomoção dos materiais de construção, com as carretas puxadas por bois, estuporando-se pelo peso que carregavam, as rodas rasgando o solo e entortando-se, seriam a metáfora de um processo civilizatório em andamento. Ao chegar ao destino, constituíam-se por um caráter desbravador que se impunha à barbárie.

Transformado o pampa com a construção do Castelo, à sua assimilação mítica entra em consonância com o que nos falam Barthes (1980), Cassirer (1992), Calvino (1977) dentre outros autores, pois o mito tem ligação com a linguagem, além de sua função restauradora $^{10}$.

9 Campos "de Cima da Serra" (também Campos de Vacaria) região localizada no extremo nordeste do RS. , na divisa de Santa Catarina, é formada por uma planície elevada de solo basáltico, em oposição à região denominada "Campanha", abaixo da serra (CORRÊA, Romaguera, et al. Vocabulário Rio-Grandense. Rio de Janeiro, Porto Alegre: Globo, 1964. p. 89).

10 LUCCIONI, Gennie; THIS, Bernard; et all. Atualidade do Mito. Tradução de Carlos Arthur R. do Nascimento. São Paulo: Duas Cidades, 1977. p.89 
O Castelo, segundo a História ${ }^{11}$, resguarda a memória de um importante momento da política do Rio Grande do Sul, pois é coadjuvante do cenário histórico que, pelo significado que emana, refere ao que Barthes(1980) chama de metalinguagem, uma vez que nos faz perceber um texto construído. Challub (2002), em obra recente, remete à intertextualidade que ocorre no processo de metalinguagem. Assim, o leitor de Um Castelo no Pampa observa o ressignificado do castelo operado pela linguagem literária, insuflado de representação, cuja "escrita e imagem (...) ambas chegam ao limiar do mito dotadas da mesma função significante (...)"12.

O fato é que ninguém, exceto o mestre e João Felício, sabia ao certo o que se edificava ali. Suas conferências tinham acentos de conspiração, e falavam através de códigos escabrosos. ${ }^{13}$

A História pode, também, se constituir por fatos ordinários, além de seus registros. Nesse sentido, seus participantes, embora se outorguem laivos épicos e suas façanhas revelem-se plenas de interesses individuais, desfazem a perspectiva de o leitor encontrar, na narrativa, o atributo épico dessa História. Mais uma vez lembramos Linda Hutcheon, quando diz que "o valor da redação da história, apenas redefine as condições de valor"14, pois, para essa autora, "a metaficção historiográfica representa um desafio às formas convencionais (correlatas) de redação da ficção e da história, (...)"15.

Os conflitos revolucionários que assolaram o Rio Grande do Sul e o Brasil, no final do século XIX e século XX, até 1964, estão retratados na obra e se apresentam intermediados por um discurso paródico, que dialoga, em combate irônico, com os fatos conhecidos através dos registros da História.

Nesse sentido, vemos que as personagens, com suas facetas controvertidas, algumas delas grotescas, todas solitárias, presas a conceitos rígidos, guardam na intimidade as mesmas angústias de todo o ser humano, com seus conflitos individuais e coletivos. Há, também, em muitos momentos, um descompasso da linguagem. Isso porque a voz narrativa é dada, propositalmente, a algum narrador que reconta a história com um olhar torpe, provocando um indefinido desconforto. Este sentimento se apodera do leitor que reage com desconfiança ao que é narrado, descobrindo-se, então, fragilizado, quase vazio em relação ao texto.

Personagens como Astor e Páris realizam um percurso circular, embora não sejam as mesmas que chegam ao final do percurso. Ambas com origem obscura, mas não indefinida, partem numa sequência de aventuras. Reconstroem as vivências familiares, vivendo à margem. Opondo-se ao sério, ao oficial, identificado pelo protagonista, desestabilizam a narrativa e servem para salientar, nesse paradigmático mundo, ascético de afetividade em que se situa o Castelo, a heterogeneidade das relações humanas. De forma hilária e, muitas vezes despertando a reflexão, Astor e Páris se tornam como uma resistência àquele mundo,

11 “(...) e a 14 de dezembro de 1923, no Castelo de Pedras Altas (residência de Assis Brasil) foi assinada a 'Ata de Pacificação'” In: ANTONACCI, Maria Antonieta. RS: As oposições \& A Revolução de 1923. Porto Alegre: Mercado Aberto, 1981. p.109

12 BARTHES, Roland. Mitologias. Tradução Rita Buongermino e Pedro de Souza. 4.ed. Rio de Janeiro: Difel, 1980. p.137

13 ASSIS BRASIL, Luiz Antonio de. Perversas Famílias. 3.ed. Porto Alegre: Mercado Aberto, 1992. p.205

14 HUTCHEON, Linda. Poética do Pós-Modernismo: história, teoria, ficção. Tradução Ricardo Cruz. Rio de Janeiro: Imago, 1991. p. 168

15 Idem. P.169 
ao removerem do mesmo a máscara que encobre o interdito; transformam-se, então, em olhos críticos da narrativa.

Dessa maneira, os elementos que fazem parte da narrativa, tais como os fragmentos crus da realidade, as vulgaridades, ou a exposição de conhecimentos eruditos, cristalizamse em uma figuração, que presentifica um determinado momento histórico. O material heterogêneo reunido na obra não está subordinado a um todo orgânico, mas se destaca de modo também controverso, para, ao final, completar o conjunto.

Decorrente dessa fragmentação de capítulos, que também fragmenta a narrativa em falas diversas, o romance de Assis Brasil, enquadra-se no conceito de polifônico, de Bakhtin. Há uma pluralidade de vozes dialógicas, formada, no entanto, de unidades independentes que constituem os diversos narradores. Coabita, ao mesmo tempo, no romance, a efervescência e a calmaria.

Testando fronteiras, L.A. de Assis Brasil mescla a História com a história por ele construída, numa constante desarticulação com o já conhecido. Isso porque sua obra insere-se numa categoria "cuja estrutura intrinsecamente paradoxal, permite interpretações contraditórias" ". O lado obscuro de seu texto exige um leitor com domínio do assunto, pois o contrário somente provoca mais obscuridade. Sua narrativa enquadra-se, então, naquilo que L.Hutcheon chamou de metaficção historiográfica, que, despertando a autorreflexividade do romance, impõe os limites do conhecimento histórico. Constitui-se em discurso paradoxal, uma vez que não nega a existência do real, porém questiona o sentido do real e como podemos conhecê-lo. Nesse viés, o fato histórico narrado pelo literário pretende conscientizar o leitor para a distinção entre os verdadeiros acontecimentos e os fatos que propiciaram dar sentido àquele passado. Pode-se dizer que o pós-moderno problematiza os limites entre o literário e o não literário, da ficção com a não ficção, lançando uma dúvida epistemológica, no momento em que põe sob suspeita a escrita da História e a textualidade de seu arquivo. A 'verdade histórica' passa a ser apreendida como uma possibilidade de verdade. O pós-moderno é, ao mesmo tempo, cúmplice e crítico das normas predominantes.

Essa cúmplice-vigilância pode ser encontrada no texto de L. A. Assis Brasil, mais precisamente quando é o protagonista que está presente. Nesse momento, o narrador posiciona-se de uma forma não contestatória, embora sem explicitar um juízo de valor sobre os atos e análises da personagem.

O romance, na pós-modernidade, denuncia a situação que diz respeito ao distanciamento do que é narrado à vida real. Há no romance tradicional uma ambição de verossimilhança, sem, no entanto, concretizar-se. Enquanto o romance, na pós-modernidade, já possui uma clareza que prescinde da busca da totalidade, a ficção tradicional não corresponde à autenticidade da vida real, sendo esta muito mais complexa e diversificada do que a que é transmitida. Opondo-se ao romance tradicional, porque aspira ao relato integral do comportamento humano, a preocupação do escritor, seu criador, é não mais engendrar a personagem em função de uma história, mas, antes, dar-lhe liberdade total, ainda que seja em sacrifício do enredo.

Nesse viés, Um Castelo no Pampa não se consolida na apropriação dos dados históricos, mas na construção de uma narrativa que, retomando a História, desestabiliza o leitor, ao enfocá-la por uma vertente crítica. Além disso, nessa obra, ressalta a erudição do autor, pois, a releitura direciona para as raízes da literatura cômica e, consequentemente,

16 HUTCHEON, Linda. Op. Cit. 279 
grotesca. A narrativa assume, dessa forma, um caráter semântico que ultrapassa o simples conhecimento dos fatos.

Concomitante às subversões históricas, ainda afloram as intertextualidades por meio de expressões que insinuam outras realidades, não dando tréguas ao leitor que se sente pequeno para tantos acenos, como, por exemplo, quando o protagonista adoece do coração. Naquela ocasião, Getúlio Vargas escreve a Olímpio aconselhando-o a consultar em Buenos Aires, pois "gaúchos decentes" precisam ir ao templo de Epidauro ${ }^{17}$, "com seus médicos modernos', para tratar tanto o físico, quanto a mente. O significado dado à capital portenha, remetendo ao mundo grego, é na verdade um recurso, assim como tantos outros usados para confundir e distrair o leitor.

Os intertextos, portanto, trazem à narrativa as mais variadas articulações, uma vez que o tecido literário, tramado, confirma o diálogo empreendido pelo romancista. Constatamos, dessa forma, que, passado e presente encontram-se quando o protagonista faz a queima de livros da época, dizendo que a melhor poesia era anterior à de $1880^{18}{ }^{19}$. Nesse momento, voltamos ao romance Don Quixote (1971), no episódio da queima dos livros inúteis ${ }^{20}$, principalmente de poesias ${ }^{21}$. Ou ainda, o neto do protagonista, relembrando um fato de sua vida, inicia suas rememorações à semelhança de Nogueira, personagem do conto Missa do Galo, de Machado de Assis(1993) ; da mesma forma, quando essa mesma personagem faz um pacto não explícito com o diabo, numa outra alusão intertextual, desta vez com Fausto, de Göethe (1997); ou, como entre tantas outras manifestações do protagonista, que, ao dialogar com Silveira Martins, o "Rei do Rio Grande", enuncia palavras $^{22}$ que lembram os versos do poema Marília, de Dirceu ${ }^{23}$. Também encontramos traços intertextuais com Erico Verissimo, por ocasião da alforria dos escravos, feita por Olímpio $^{24}$, ou no emprego da palavra Liberdade ${ }^{25}$.

17 ASSIS BRASIL, Luiz Antonio de. Pedra da Memória. Porto Alegre: Mercado Aberto, 1994. p.363

18 "Como não bastasse a escassez, o Doutor um dia incinera 132 livros de poesia, dos quais reserva os clássicos ao estilo de Camões e Dante."

19 ASSIS BRASIL, Luiz Antonio de. Pedra da Memória. Porto Alegre: Mercado Aberto, 1994. p. 114

20 CERVANTES. "Del donoso y grande escrutínio que el cura y el barbero hicieron en la libreria de nuestro ingenioso hidalgo".

21 CERVANTES. “(...) Bien los puede vuestra merced mandar quemar, como a los demás; porque no sería mucho que, habiendo sanado mi señor tío de la enfermedad caballeresca, leyendo éstos se le antojase de hacerse pastor y andarse por los bosques y prados cantando y tañendo y, lo que sería peor, hacerse poeta, que, según dicen, es enfermedad incurable y pegadiza".

22 "Não tenho estância que seja só minha. Mas de minha parte eu penso que sei dar conta". In: ASSIS BRASIL, Luiz Antonio de. Perversas Famílias. 3.ed. Porto Alegre: Mercado Aberto, 1992.

23 “Eu, Marília, não sou algum vaqueiro, Que viva de guardar alheio gado; De tosco trato, d' expressões grosseiro, /Dos frios gelos, e dos sóis queimado./Tenho próprio casal, e nele assisto; /Dá-me vinho, legume, fruta, azeite; /Das brancas ovelhinhas tiro o leite, /E mais as finas lãs, de que me visto." (grifo nosso) In: GONZAGA, Tomás Antonio. Marília de Dirceu. São Paulo: Ediouro, s/d. p. 15

24 Esse fato, de forma festiva, construindo uma intertextualidade paródica remete à festa de Licurgo Cambará, ao alforriar seus escravos. "A entrega dos títulos de manumissão foi feita no meio dum silêncio grave e comovido. Os escravos estavam no quintal, junto da porta da cozinha, e entravam à medida que seus nomes iam sendo chamados. Sob o espelho da sala de visitas, os títulos empilhavam-se em cima do consolo de mármore. Toríbio Rezende lia a lista de nomes (...) e, muitas vezes Licurgo tinha de soprar-lhe ao ouvido o apelido do negro chamado, pois muitos daqueles homens já haviam esquecido os nomes de batismo. (...) Licurgo, então, sentiu com tamanha e repentina força a beleza daquele instante, que esteve quase a rebentar em lágrimas". (VERISSIMO, 5. ed. , p. 599-601)

25 Em mais uma intertextualidade com Erico Verissimo, em Incidente em Antares, o próprio autor L. A. Assis Brasil faz alusão ao diálogo de uma criança com seu pai, no prólogo de um capítulo de Perversas Famílias, p. 160. Alude à fala da criança soletrando a palavra liberdade, a qual, naquele contexto, é proibida e, assim, a criança é repreendida pelo pai. (VERISSIMO, 1999. p. 484) 
Vemos então que esses intertextos, semeados ao longo da narrativa, recuperando aspectos dos cânones literários, mostram-se enriquecedores e reforçam, segundo nossa visão, a intenção do autor em seduzir, por essa via, o leitor. Aqui, em um primeiro momento, como já foi mencionado, damos ênfase à evidente erudição do autor, que parece indicar um caminho interpretativo. No entanto, logo depois, o narrador desestabiliza nossas certezas, fomenta nossa insegurança e, por não ser confiável, nos direciona por outras trilhas. Esse aspecto do narrador é fundamental, pois leva o leitor por uma hermenêutica que o distancia daquilo que lhe fora acenado e que ele passou a supor como verdade. Para Paul Ricouer ${ }^{26}$, o narrador não confiável desordena as expectativas do leitor, provocando incertezas e não dando garantias de verdade, pois esse é o seu papel. Para esse teórico, "quanto mais suspeito for o narrador" melhor o romance exercerá "sua função de crítica da moral convencional, eventualmente sua função de provocação e de insulto" 27 , o que, de certa forma, vem ao encontro e fortalece o que apregoa a metaficção historiográfica.

Questões como a polifonia, o carnaval, a ironia, o grotesco, o mítico, tornam mais evidente a condição pós-moderna da narrativa. Disseminadas, fazem com que as personagens atuem de forma plena, com seus traços característicos. A polifonia perpassa a obra aglutinando e difundindo as vozes, de modo que, em cada capítulo, o narrador é substituído, formando um marulhar de discursos. O carnaval, a ironia, o grotesco são categorias de análise, que, marcadamente, identificam personagens como Páris e Astor. Para essas personagens, o real constitui-se sempre de forma distorcida. Cada uma delas vive o seu próprio universo, desafiando o estabelecido, como uma maneira de contestar a vida. Astor e Páris são as personagens masculinas sinalizadas pelo pecado que ronda a narrativa. $\mathrm{O}$ primeiro, filho bastardo, e o segundo, filho de um casamento não aprovado pela família. Ambos, frutos de amorosa entrega.

A trama, costurada em cada capítulo, forma, no seu conjunto uma tessitura muito particular. Se fosse possível projetar a imagem dessa textualidade seria um caleidoscópio colorido. Todavia a técnica usada, traduzindo-se por uma diversidade de vozes, parece indicar que as diferentes perspectivas de narradores são conflitantes, mas, na verdade, são complementares. Há um jogo do autor, como se fosse jogo de esconder, para criar uma expectativa de grandes segredos que seriam desvelados, e, no entanto, se descobrem conhecidos. Não há nada atrás da cortina. $\mathrm{O}$ que temos presente são as personagens que vêm ao palco para rememorar fatos de suas vidas, assomando, nessas lembranças, uma série de acontecimentos da época em que foram vivenciados, bem como mostrando, abertamente, sem subterfúgios as rupturas sociais. E paira, no passado ou no futuro, a presença do protagonista, Olímpio, que sintetiza uma espécie de ideal.

O ponto de vista da narrativa divide-se, pois, entre vários narradores: em terceira pessoa ou em primeira pessoa, incluindo-se nesses últimos Astor, Páris, Selene e Proteu e que se constituem em consciência crítica dos acontecimentos narrados, como já foi mencionado. Além desses narradores, o romance ainda inclui outros textos paralelos àquele mundo, mas que têm seu lugar de significação na obra, como "A cozinheira: Zulmira Pacheco", “A copeira: Antônia Guedes", "O jardineiro: Jones”.

Um narrador que se mostra implacável com a personagem é o de D. Plácida, fundadora da família. Ela, por ter rompido com seu papel tradicional de viúva, escancarando seus desejos sexuais, foi julgada sem piedade pelo narrador irônico e mordaz que

26 RICOEUR, Paul. Tempo e Narrativa - Tomo III. Tradução Roberto Leal Ferreira; revisão técnica Maria da 
a trata, arrogantemente, com o pronome em segunda pessoa. Onisciente, dirige-se a ela interpelando-a e mortificando-a.

As personagens, cujo relato passa pela censura do narrador, chegam até o leitor, com uma crítica abrandada. Encontra-se nessa visão o próprio Olímpio, a Condessa e Arquelau.

O humor que se pode ler em muitas passagens não se dirige a todas as personagens, mas sua corrosiva ação tem alvo definido: o protagonista. Ele é o destinatário, por exemplo, de muitas das mordazes falas de Astor, de Proteu e de Páris. Cada um, a sua maneira, vai discorrendo sobre a personagem, cujo percurso, linear e ascendente, está em contraponto com o que já realizaram. De fato, ao observarmos o protagonista, vemos que seu trânsito, nos mais diversos círculos de relações, é absolutamente seguro, indicando, desse modo, sua presença. Exerce um fascínio, tanto negativo quanto positivo. Sua construção verossímil traz à tona as incongruências humanas. $\mathrm{O}$ autor, retomando momentos históricos grandiosos, molda uma personagem anti-heróica que tem consciência de sua importância e que, ao mesmo tempo, reduz sua grandeza ao mover-se por objetivos mesquinhos.

Com enriquecedoras possibilidades, ainda nos instiga o texto. Assim, personagens como Beatriz, Hermes, ou os empregados, que fizeram jus a capítulos especiais, ou fatos como a morte de Getúlio, ou o nascimento de bebês quando Beatriz, Páris ou Astor estavam por perto, ou, ou episódio de Páris no Rio de Janeiro ao encontrar Aquiles - esse momento, pela grande mescla de elementos, muitos deles hilários, tem uma forte aproximação à leitura de Macunaíma - , e até mesmo as aves estrangeiras - pardais - aves nobres - trazidas por Olímpio da Europa dão ao texto um caráter peculiar.

A par disso, pontua os paradoxos da sociedade de senhores da elite rural que personificam o poder constituído, e que, embora apegados às suas terras, não conseguem superar a atração que sentem pela cultura estrangeira, contaminando-se com ela. Ao refazer aspectos da vida da campanha, os valores prezados pelo homem do campo são confrontados com costumes urbanos.

Da mesma forma, podemos participar do corajoso ato do Doutor Olímpio ao enfrentar os soldados monárquicos, na Guerra de 93 , parando o trem em que os mesmos se locomoviam rumo a Bajé, enquanto sua esposa, Charlotte, num gesto habitual, guarda o binóculo no "estojo de veludo vermelho"28, após observar, da torre do Castelo, a ação do marido.

Descrições insignificantes como o gesto de Charlotte, inseridas no mesmo contexto de um fato histórico, fazem com que a singularidade histórica passe para o plano da universalidade da vida humana. Essa falsa simplicidade, dada pelo narrador ao gesto de Charlotte, corrobora a importância do acontecimento protagonizado por seu marido. $\mathrm{O}$ fato histórico preenchido desse modo pela mão do ficcionista resgata, pelo gesto, aquilo que Barthes chama "o efeito do real", criando com o leitor uma certa cumplicidade que o faz aceitar o jogo narrativo, mesmo que a forma utilizada pelo autor provoque desconforto.

Luiz Antonio de Assis Brasil embora seja identificado por seus trabalhos anteriores como um autor que preenche as lacunas da História, como em Videiras de Cristal, sua narrativa em Um Castelo no Pampa não se processa da mesma forma. Os conflitos revolucionários que assolaram o Rio Grande do Sul e o Brasil apresentam-se intermediados por um discurso paródico, dialogando, em combate irônico com os registros da História. Assim o fato histórico apresenta-se, também, nesse momento, lado a lado a fatos domésticos. Desse modo, ao correlacionar acontecimentos e rotina diária no Castelo, trazendo o corriqueiro da vida de cada personagem para entremear com fatos que construíram a 
História do Rio Grande do Sul, o autor transgride o já conhecido, universalizando e banalizando sua perspectiva.

O teórico Hayden White (1995), estudioso dos fatos da História, chama a atenção para a mobilidade das fronteiras do conhecimento histórico. Nesse viés, observamos que, no romance, o modo de apreensão da História se faz pelo ângulo da ironia. Esta aparece como desarticuladora dos encaixes da trama, portanto desequilibra qualquer tentativa de submissa aceitação da obra de arte. Seria, nesse caso, como enquadrá-la, por analogia, às categorias do texto poético, salientadas por Friedrich ${ }^{29}$. Por essa percepção, dizemos que o texto de Assis Brasil, ao distanciar-se do tradicional romance histórico, pela transgressão, constrói uma metaficção, segundo o que nos diz Hutcheon (1991). Reconstrói, então, outro passado, a partir daquilo que é conhecido como verdade histórica e lança um novo modo de ler a História ao aproximar a realidade histórica a um modo de contar que difere do que até então seu leitor habituara-se. Suas personagens constroem-se de acordo com a técnica do romance pós-moderno, pois interessado em tirar partido de situações peculiares da vida das mesmas mostra um enredo sem o compromisso de revelar o conhecimento objetivo do passado. Assim, o escritor olha para esse passado com ironia, uma vez que esse tropo lingüístico não pretende, segundo o que nos diz Muecke ${ }^{30}$, "dizer alguma coisa e dar a entender o contrário", mas "é dizer alguma coisa de uma forma que ative não uma, mas uma série infindável de interpretações subversivas".

Uma das possibilidades, portanto, da abordagem irônica no texto de Assis Brasil é vê-lo como uma ruptura com relação à tradição do romance no Rio Grande do Sul.

Assim, a tensão da trama histórica trazida pela releitura do passado é mediada por uma aguda crítica, que ultrapassa a fronteira do histórico, diluindo os conflitos em pequenas e irônicas enunciações. Como ocorre na interpretação do narrador sobre os acontecimentos vividos: "revoluções são inevitáveis no pampa. Acontecem com a fatalidade dos furúnculos nos corpos envenenados" 31 .

E as personagens que possuem a mesma descendência e participam do mesmo contexto político-social exibem o passado, a ancestralidade de um clã, a visão de diferentes gerações em uma percepção irônica, como se fosse o olhar do próprio autor. Nesse aspecto, Jameson diz que "a atividade do romancista se desenvolve sempre sob o signo da ironia". ${ }^{32}$

Sabemos que o tropo da ironia exterioriza ceticismo, além de ser explicitamente negacional, ou seja, negando, muitas vezes, implicitamente o que é dito explicitamente. Por isso, ao exteriorizar, usa no discurso a tonalidade da voz para esconder-se em sua dialética. A ironia, escreve White, "Chama a atenção para a tolice potencial de todas as caracterizações lingüísticas da realidade, tanto quanto para a absurdidade das crenças que ela parodia",33

Para Kierkegaard (1991), a ironia serve à realidade, pois lhe dá ênfase e colorido. Wayne C. Booth (1974) aborda a questão da ironia tentando definir seu contorno, resgatando a sutileza da palavra.

Enfocar, então, a ironia em Um Castelo no Pampa, é percebê-la a partir de seu potencial de criticidade, uma vez que é também empregada como recurso estilístico. Por

29 Esta junção de incompreensibilidade e de fascinação pode ser chamada de dissonância, pois gera uma tensão que tende mais à inquietude que à serenidade. A tensão dissonante é um dos objetivos das artes modernas em geral, segundo pensamento de FRIEDRICH. (1991).

30 MUECKE, D. C. Ironia e o Irônico. São Paulo; Perspectiva, 1995. p. 48

31 ASSIS BRASIL, Luiz Antonio de. Pedra da Memória. Porto Alegre: Mercado Aberto, 1994. p. 168

32 JAMESON, Fredric. Marxismo e Forma: Teorias Dialéticas do Século XX. São Paulo: Hucitec, 1985.p.137

33 WHITE, Hyden. Op. Cit. p. 51 
isso, é condição fundamental numa narrativa que aspire à lucidez (que tem origem na criticidade). Desse modo, sua utilização exige uma perspectiva vigilante no sentido de não torná-la prisioneira da pura crítica gerada por ela mesma. A ironia também pode ser, em outro sentido, um fator de distanciamento dos fenômenos do mundo, visto que sua capacidade crítica a impossibilita de compreender a visão metafórica da realidade. Acreditamos que este tropo lingüístico torna-se ponto de partida para todo o entendimento que se queira crítico.

Articulando com o discurso histórico, o texto reflete no literário a abolição da escravatura, a queda da Monarquia, a proclamação da República, os governos positivistas no Rio Grande do Sul e a relação com o governo central. Do mesmo modo, são referidos os vultos que participaram desses acontecimentos, como Silveira Martins, Joaquim Francisco de Assis Brasil, Borges de Medeiros, Júlio de Castilhos, Getúlio Vargas, dentre muitos outros. Recuperam-se os registros engessados pelo distanciamento e, que, lidos através da arte, fundem as categorias da História e da Literatura.

Sobre essas fronteiras do literário já nos direcionou o autor da Poética, ao dizer que "não era ofício do poeta narrar o que aconteceu; é sim, o de representar o que poderia acontecer, ou o que era possível, segundo a verossimilhança e a necessidade". A diferença entre o historiador e o poeta estava precisamente nisto: "um narra as coisas que sucederam, e outro, as coisas que poderiam acontecer"34.

Mikhail Bakhtin, no entanto, faz alusão a outra possibilidade, ao mencionar os diálogos de Sócrates, como a origem do romance, pois diz que, nesses escritos, já estão contidas as primeiras referências de uma concepção de linguagem revolucionária, juntamente com uma visão de mundo diferenciada. Para esse pensador, Sócrates deixou "um documento notável que reflete o nascimento simultâneo do conceito científico e da nova personagem romanesca na arte literária em prosa". ${ }^{35}$

Por outro lado, Hayden White (1995), reviu a conceituação aristotélica em sua obra Meta-História, ao estudar a historiografia do século XVII baseada nos " 'romans de intrigas e amores"”, vendo nessas antigas histórias eclesiásticas e de eruditos o possível embrião do romance histórico.

(...) A vocação metafórica desses relatos, em que não havia nenhuma preocupação com o rigor dos fatos ocorridos, mas onde eram eles tão-somente uma espécie de suporte para a narrativa principal, fez com que essa forma de história fosse desprezada pelas principais correntes intelectuais da época ${ }^{36}$, embriagadas pelo rigoroso elixir do positivismo que nascia. (...) Na verdade, o destino dessa historiografia préiluminista não poderia ser outro, já que ela mesma não se levava muito a sério. Não se proclamava como uma narrativa dos fatos que aconteceram, mas se imaginava como uma ficção especulativa. ${ }^{37}$

No estudo das relações entre História e ficção, White afirma sobre as histórias romanescas do século XVII, que:

34 ARISTÓTELES. Tradução E. Souza. São Paulo: Ars Poética, 1992. p. 53

35 BAKHTIN, Mikhail. Questões Literatura e de Estética. Tradução Aurora Bernardini et al, 3.ed.São Paulo: Hucitec, 1993. p.414

36 A historiografia racionalista do Iluminismo postulava que a história não deveria servir somente para 'entreter' mas, que deveria ter um princípio crítico para o qual pudesse direcionar a reflexão sobre o registro histórico. Por isso, como expõe Hayden White, (1995, p. 72) os philosophes, como Kant, criticaram esse modo de relatar a história, “dizendo que ela “devia ser 'veraz' ou não poderia pretender instruir e esclarecer o leitor no processo de o 'entreter e deleitar' ". (MENNA BARRETO, 2000, p. 26)

37MENNA BARRETO, Eneida Marília Weigert. Demônios e Santos no Ferrabrás: uma leitura de Videiras de Cristal. Porto Alegre: UFGRS, 2000. p. 26 
(...). Se Saint-Réal pouco mais fez do que 'divertir' seus leitores ao escrever 'nouvelles amusantes et émouvantes', suas histórias, (...) assinalavam um desejo de alcançar uma perspectiva crítica que ao mesmo tempo distanciasse os fenômenos a representar e os unisse num todo compreensível, ainda que o todo fosse pouco mais do que uma estória emocionante. No entanto, como a única unidade que as histórias de SaintReal têm é a da estória concebida como pouca coisa mais do que um artifício para alcançar efeitos retóricos, as histórias que ele de fato escreveu são falhas pelo fato de que, segundo suas próprias palavras, representam não uma 'verdade acerca do passado mas apenas uma 'ficção' de como os fatos poderiam ter sido. ${ }^{38}$

Essa questão, ainda discutida na atualidade, esteve presente no debate sobre o realismo no século XIX. A História aparece, pois, como aquilo que foi, o que verdadeiramente aconteceu, e a narrativa romanesca como o que poderia ter sido.

O romance histórico, como sabemos, teve larga penetração no Romantismo, especialmente no decorrer do século XIX, lançando uma nova percepção sobre o passado - como se observa nos romances de W. Scott, de V. Hugo e de A. Herculano, na Europa, e, entre nós, em algumas obras de José Alencar. Entretanto, apesar das profundas transformações do romance moderno, não se pode dizer que a História tenha desaparecido da narrativa no Século XX, haja vista as inúmeras narrativas, na atualidade, cujos autores retratam essa perspectiva. -

As nuanças da narrativa de L. A. Assis Brasil reconstroem, de forma explícita, relações da fiç̧ão com fatos históricos. Na transgressão literária o leitor é conduzido a identificar a personagem ficcional Olímpio com a personagem histórica Joaquim Francisco de Assis Brasil. Além disso, verificamos que a articulação com a História não se faz de forma tradicional, épica, mas contrapõe outra versão à oficial, sem a crença de que a História tenha a posse da verdade. Por oficial, podemos considerar que a História do Rio Grande do Sul foi constituída de forma épica no romance $O$ Tempo e o Vento, de Erico Verissimo; e L. A. Assis Brasil desvela o lado mesquinho e sórdido dos grandes homens que fizeram a "gloriosa" história de guerras no solo gaúcho.

Assim, Olímpio ${ }^{39}$, personagem desse mundo ficcional, retratado como o chefe de uma família oligárquica, assume valores republicanos, e, paradoxalmente, preserva hábitos aristocráticos.

Em Um Castelo no Pampa as relações intertextuais centralizam-se na interdisciplinaridade entre História e Literatura e é possível perceber a questão da ironia como uma ruptura. Nesse sentido, a abordagem crítica fundamenta-se em teóricos como White, Hutcheon, Veyne, Le Goff, entre outros. E a questão da historicidade, vista pelo viés da metaficção historiográfica, estabelece elos entre a Sociologia literária, a Crítica literária e a Literatura Comparada.

A pesquisa bibliográfica apoia-se nos procedimentos metodológicos da Literatura Comparada. Nesse sentido, a comparação não se faz de forma superficial, simples cotejo de textos, mas em um estudo abrigado na própria natureza da Literatura Comparada. Esta, ao possibilitar a aproximação entre textos, literaturas e culturas, através da leitura de fatos históricos, culturais e sociais decisivos, apontando confluências e sublinhando diferenças, propicia um diálogo entre os mesmos que, de acordo com Tania Carvalhal ${ }^{40}$, "não é um

38 WHITE, Hyden. Op. Cit. p. 74

39 Escolhemos Olímpio como protagonista, muito embora, no decorrer do texto, outras personagens também pudessem desempenhar essa função.

40 CARVALHAL, Tania Franco. Literatura Comparada. 2.ed. São Paulo: Ática,1992.p.53 


\section{Conexão Letras}

processo tranqüilo nem pacífico". Esse espaço, em que estão dialeticamente inseridas essas estruturas textuais e extratextuais, é um território de enfrentamento que propicia aos comparatistas a descoberta de novos conhecimentos e indagações no campo literário.

A obra literária que tem a liberdade de olhar para o passado revela a sua contemporaneidade, ao construir um passado não épico, porém mais humano e possível. É por isso que, muitas vezes, os narradores de Um Castelo no Pampa parecem fazer parte de cenas jocosas, transparecendo a idéia de que, em todas as épocas, a História pode ser lida também como uma comédia que não se leva a sério. Esse procedimento, entretanto, oculta outra noção presente que é a História como denúncia, como conflito de gerações e de interesses.

A partir dos dados históricos, o narrador/autor desfaz toda e qualquer interpretação de bravura na História do Rio Grande do Sul, revelando a falsidade e o acaso que norteiam o heroísmo da historiografia rio-grandense. O autor, ao utilizar a metaficção historiográfica, constrói um novo passado. Ao fragmentar a narrativa em múltiplas vozes, desautoriza a tentativa do leitor do século XXI de encontrar apenas uma verdade e, com isso, firma a impossibilidade de uma percepção única da verdade histórica.

Os títulos dos volumes que compõem a obra estão contextualizados: em Perversas Famílias, Proteu, depois de morto, desabafando, externa a infelicidade de pertencer a essa família, afirmando ter sido "um peso carregar esse nome famoso - essas grandes famílias... essas perversas famílias". 41

Em Pedra da Memória, há a alegoria presente nas pedras que edificaram o Castelo. A construção abriga a memória: da família, da Província, das pessoas que fizeram a história do Castelo. Essa é a pedra que resguarda toda uma época, para ser desvendada, no momento oportuno, pelos narradores. Assim, as personagens abrem as portas do Castelo, cujas pedras escondem a sabedoria de séculos, mas, também permitem a ocultação de seus interditos.

Em Os Senhores do Século o relato finaliza. São retomadas de forma ambígua as questões históricas da política brasileira e rio-grandense. Os senhores do século definem seu lugar na história. O panorama dos acontecimentos políticos retrata o jogo de interesses, a manipulação. Exibidas as mazelas, levantam a suspeição sobre a autoridade estabelecida.

No conjunto da produção literária de Luiz Antonio de Assis Brasil, talvez seja a obra Um Castelo no Pampa aquela que mais desperte polêmica entre os leitores, pois não se mostra complacente com os mesmos: os acontecimentos que focaliza têm o traço contundente da ironia.

Ao fazer um painel da História do Rio Grande do Sul de meados do século XIX até 1964, revolvendo um passado cheio de contradições políticas e sociais, com diferentes momentos efervescentes na vida do país e do mundo, Luiz Antonio de Assis Brasil ultrapassa as barreiras de seu tempo, transpõe fronteiras discursivas e instaura-se na pósmodernidade. Conquista, desse modo, seu lugar definitivo ao lado dos maiores nomes da Literatura Sul-Rio-Grandense.

\section{Referências}

ANDERSON, Perry. As origens da Pós-Modernidade. Tradução Marcus Penchel. Rio de Janeiro: Jorge Zahar, 1999. 
ANDRADE, Mário. Macunaíma - o herói sem nenhum caráter. São Paulo: Secretaria da Cultura, Ciência e Tecnologia, 1978.

ANTONACCI, Maria Antonieta. RS: As oposições \& A Revolução de 1923. Porto Alegre: Mercado Aberto, 1981.

ARISTÓTELES. Tradução E. Souza. São Paulo: Ars Poética, 1992.

ASSIS BRASIL, Joaquim Francisco. A Atitude do Partido Democrático Nacional na Crise da Renovação Presidencial para 1930-34. Porto Alegre: Globo, 1929.

ASSIS BRASIL, Luiz Antonio de. Perversas Famílias. 3.ed. Porto Alegre: Mercado Aberto, 1992.

ASSIS BRASIL, Luiz Antonio de. Pedra da Memória. Porto Alegre: Mercado Aberto, $1994 \mathrm{a}$.

ASSIS BRASIL, Luiz Antonio de. Senhores do Século. Porto Alegre: Mercado Aberto, $1994 b$.

ASSIS BRASIL, Luiz Antonio de. 2.ed. Videiras de Cristal. Porto Alegre: Mercado Aberto, 1991.

BAKHTIN, Mikhail. A Cultura Popular na Idade Média e no Renascimento. Tradução Yara Frateschi Vieira. São Paulo: Hucitec, 1987.

BAKHTIN, Mikhail. Questões Literatura e de Estética. Tradução Aurora Bernardini et al, 3.ed.São Paulo: Hucitec, 1993.

BARTHES, Roland. Mitologias. Tradução Rita Buongermino e Pedro de Souza. 4.ed. Rio de Janeiro: Difel, 1980.

BARTHES, R. O Prazer do Texto. São Paulo: Perspectiva, 1993.

BARTHES, Roland. O Rumor da Língua. Tradução Mário Laranjeira.2.ed. São Paulo: Martins Fontes, 2004.

BOOTH, C. Wayne. A Rethoric of Irony. Chicago and London: The University of chicago Press, 1974.

BRAIT, Beth (org.).Ironia em perspectiva polifônica. Campinas: UNICAMP, 1996.

BRAIT, Beth (org.).Bakhtin, dialogismo e construção do sentido. Campinas: UNICAMP, 1997.

BRANDÃO, Junito de Souza. Mitologia Grega. 13.ed. Vol.: I,II, III. Petrópolis: Vozes, 2002.

CALVINO, Italo. A combinatória e o mito na arte da narrativa. In: Atualidade do Mito. Tradução Carlos Arthur R. do Nascimento. São Paulo: Duas Cidades, 1977.

CANDIDO, Antonio et al. A Personagem de Ficção. 9.ed. São Paulo: Perspectiva, 1995. CARVALHAL, Tania Franco. Literatura Comparada. 2.ed. São Paulo: Ática,1992.

CASSIRER, Ernst. Linguagem e Mito. 3.ed. São Paulo: Perspectiva, 1992.

CERVANTES, Miguel de. Don Quijote de la Mancha. Barcelona: Editorial Juventud, 1971.

CÉSAR, Guilhermino. História da Literatura do Rio Grande do Sul. Porto Alegre: Globo, 1956.

CHALLUB, Samira. A Metalinguagem. 4.ed. São Paulo: Ática, 2002.

CHIAPPINI, Lígia. O Foco Narrativo. São Paulo: Ática, 2002.

COMTE, Auguste. Discurso sobre o Espírito Positivo. Tradução Maria Ermantina Galvão G. Pereira, São Paulo: Martins Fontes, 1990.

CORRÊA, Romaguera, CORUJA, Antônio, et all. Vocabulário Rio-Grandense. Rio de Janeiro: Globo, 1964.

COSTA, Lígia Militz da. Representação e teoria da Literatura - dos gregos aos pósmodernos -. Cruz Alta: Unicruz, 1998. 


\section{Conexão Letras}

ECO, Humberto. Sobre a Literatura. Tradução Eliana Aguiar. Rio de Janeiro: Record, 2003.

ELIADE, Mircea. Mito e Realidade. São Paulo: Perspectiva, 1994.

FLORES, Moacyr. História do Rio Grande do Sul. 7.ed. Porto Alegre:EDIPLAT, 2003.

FRANCO, Sérgio da Costa. Júlio de Castilhos e sua época. 2.ed. Porto Alegre: UFRGS / Universidade, 1988.

FRANCO, Sérgio da Costa. A Guerra Civil de 1893. Porto Alegre: Editora da Universidade/ UFRGS, 1993.

GONZAGA, Tomás Antonio. Marília de Dirceu. São Paulo: Ediouro, s/d.

GOETHE, Johan W. Fausto. Tradução de Jenny Klabin Segall. 4. ed. Belo Horizonte: Itatiaia, 1997.

HUGO, Victor. Do Grotesco e do Sublime. Tradução e notas de Célia Berretini. São Paulo: Perspectiva, 1988. p. 25-6.

HUTCHEON, Linda. Poética do Pós-Modernismo: história, teoria, ficção. Tradução Ricardo Cruz. Rio de Janeiro: Imago, 1991.

JAMESON, Fredric. Marxismo e Forma: Teorias Dialéticas do Século XX. São Paulo: Hucitec, 1985.

KAYSER, Wolfang. O Grotesco. São Paulo: Perspectiva, 1986.

KIERKEGAARD, S.A. O Conceito de Ironia: constantemente referido a Sócrates. Tradução de Álvaro Luiz Montenegro Valls. Rio de Janeiro: Vozes, 1991.

LEENHARDT, Jacques; PESAVENTO, Sandra Jatahy (Orgs). Discurso Histórico e Narrativa Literária. Campinas: Unicamp, 1998.

LE GOFF, Jacques et al. A Nova História. Tradução Maria Helena Arinto; Rosa Esteves. Coimbra: Livraria Almedina, 1990.

LINS, Ivan. História do Positivismo no Brasil. São Paulo: Companhia Editora Nacional, 1967.

LUCCIONI, Gennie; THIS, Bernard; et all. Atualidade do Mito. Tradução de Carlos Arthur R. do Nascimento. São Paulo: Duas Cidades, 1977.

MACHADO de ASSIS. Contos. 17 ed. São Paulo: Ática, 1993.

MENNA BARRETO, Eneida Marília Weigert. Demônios e Santos no Ferrabrás: uma leitura de Videiras de Cristal. Porto Alegre: UFGRS, 2000.

MUECKE, D. C. Ironia e o Irônico. São Paulo; Perspectiva, 1995.NETO, J. Simões

PERRONE-MOISÉS, Leyla. Flores da Escrivaninha. São Paulo: Companhia das Letras, 1998.

PESAVENTO, Sandra Jathay. História do Rio Grande do Sul. 9 ed. Porto Alegre: Mercado Aberto, 2002.

RICOEUR, Paul. Tempo e Narrativa - Tomo III. Tradução Roberto Leal Ferreira; revisão técnica Maria da Penha Villela Petit. Campinas: Papirus, 1997.

VERISSIMO, Erico. O Tempo e o Vento: O continente. 5.ed. Rio de Janeiro: Globo, 1952.

VERISSIMO, Erico. O Tempo e o Vento III - Arquipélago. Globo: Porto Alegre, 1961. WHITE, Hayden. Meta-História: A imaginação Histórica do Século XIX. Tradução de José Laurênio de Melo. 2.ed. São Paulo: EDUSP, 1995. 